\title{
Lumen
}

Selected Proceedings from the Canadian Society for Eighteenth-Century Studies

\section{The Figure of Sarastro: Some Considerations}

\section{Jay Macpherson}

Volume 25, 2006

URI : https://id.erudit.org/iderudit/1012079ar

DOI : https://doi.org/10.7202/1012079ar

Aller au sommaire du numéro

Éditeur(s)

Canadian Society for Eighteenth-Century Studies / Société canadienne d'étude du dix-huitième siècle

ISSN

1209-3696 (imprimé)

1927-8284 (numérique)

Découvrir la revue

Citer cet article

Macpherson, J. (2006). The Figure of Sarastro: Some Considerations. Lumen, 25,

83-101. https://doi.org/10.7202/1012079ar

Copyright (C Canadian Society for Eighteenth-Century Studies / Sociéte canadienne d'étude du dix-huitième siècle, 2006
Ce document est protégé par la loi sur le droit d'auteur. L'utilisation des services d'Érudit (y compris la reproduction) est assujettie à sa politique d'utilisation que vous pouvez consulter en ligne.

https://apropos.erudit.org/fr/usagers/politique-dutilisation/ 


\section{The Figure of Sarastro: Some Considerations}

When late in the first half of Mozart's Die Zauberflöte (The Magic Flute), $1791,{ }^{1}$ Sarastro arrives, in a procession of attendants and riding in a triumphal chariot drawn by six lions (nowadays he usually enters on foot), he immediately takes his place as the presiding central figure, comparable to the king in a Shakespeare comedy or to Prospero in The Tempest. Lions are royal beasts, ${ }^{2}$ and Sarastro is returning from the kingly sport of hunting. By that point we are coming to understand that the authority figure we met earlier, the Queen of the Night, is, so to speak, an imposter, who with her passion and pathos has misled both the hero Tamino and us in portraying Sarastro as an evil demon preying on a respectable family. His dignity, wisdom, and compassion, at least towards the characters we care about, are from that later point never in doubt. As Judith Eckelmeyer has said, he is 'a spiritual prince. ${ }^{3}$

Evidently, though it is never exactly stated, Sarastro is the high priest of Isis and Osiris at an unnamed Egyptian temple and leader of its college of priests, but at the same time a ruler who deals out justice and who also, though briefly, allows the possibility of love to cross his mind. This last is just hinted, in his first words to the heroine Pamina: 'Stand up,

1 All references are to Die Zauberflöte: Max Slevogts Randzeichnungen zu Mozarts Handschrift (drawings in the margins of Mozart's ms.), mit dem Text von Emanuel Schikaneder, ed. Friedrich Dieckmann (Frankfurt: Insel, 1990) [henceforth Dieckmann]. Text references are to act and scene.

2 To these lions (they return momentarily in 2.19) Schikaneder evidently sacrificed the original opening, where Tamino expected to fall victim to a fierce lion ('dem grimmigen Löwen') rather than a crafty snake ('der listigen Schlange'): see Dieckmann, 13.

3 The Cultural Context of Mozart's 'Magic Flute' (Lewiston, NY: Edward Mellen, 1991), 1:78. 
take comfort, dear girl! / Without pressing you for information / I know more of your heart [than you are telling me]; / You dearly love another./ I will not force you to love ... ${ }^{4}$ Two diverging texts still to be mentioned vary that fourth line: 'This [my] heart is subject to your love'; 'It [your heart] is empty of love for me. ${ }^{5}$ If we take Sarastro's speech as these writers do, it would link Sarastro to a standard topic of heroic opera, where rulers from Händel's Xerxes to Mozart's Tito choose as consorts women already committed to others, and then prudently or magnanimously change their minds. They do so mainly in order not to disoblige the men concerned. Similarly, Sethos, whose story in Jean Terrasson's 1731 novel so titled helped shape the Flute's act 2, hands the princess whom he loves, and who loves him, to his (half-) brother. ${ }^{6}$ Schikaneder's different handling here reflects perhaps both his special regard for this heroine and his more bourgeois-modern attitudes.

Sarastro's priestly function is the one most in view, reinforced by his name, which derives from Zoroaster, most ancient of the great religious teachers - called 'Zoroastro' in an earlier opera I shall mention shortly. Twenty years before, in 1771, Anquetil-Duperron's translation of the Avesta had shed new light, if not on Zoroaster himself, on the religion he founded or refounded; but that was hardly of concern to Schikaneder, any more than it was to Mozart when on February 19th, 1786, he borrowed the name for a Carnival masquerade in the court ballroom in Vienna, where he handed out printed leaflets containing riddles and

4 'Steh auf, erheitre dich, o Liebe! / Denn ohne erst in dich zu dringen / weiss ich von deinem Herzen mehr; / Du liebest einen andern sehr. / Zur Liebe will ich dich nicht zwingen ...' (1.18).

5 'Dies Herz ist deiner Liebe Spiel' (C. A. Vulpius, Die Zauberflöte, 1794, ed. Hans Löwen [Leipzig: Insel, 1911], 1.23, 43); 'Es ist für mich von Liebe leer' (caption of the one non-numbered, double-width print [see Figure 1 below] in the series of seven unsigned engravings published by J. C. Zimmer and evidently based on F. L. Schröder's four-act version staged in Hamburg from 19 November, 1793). These are reproduced and discussed, along with most of the engraved illustrations of the opera to 1826 and many later, by Friedrich Dieckmann in his Zauberflöte edition (see 186-90). This line and other divergences in the Hamburg text, understood by contemporaries to be the work of F. L. Schröder (see Julius Cornet, Die Oper in Deutschland 25, as quoted by Günter Meinhold, Zauberflöte und Zauberflöten-Rezeption [Frankfurt: Peter Lang, 2001], 59), have been argued by Michael Freyhan in his 'Rediscovery of the 18th-Century Score and Parts of 'Die Zauberflöte' showing the text used at the Hamburg première in 1793' (Mozart-Jahrbuch 1997, 109-147) to derive from a score sold by Mozart's widow in 1792.

6 The reasons here are somewhat different: see Sethos, histoire ou vie tirée des monumens anecdotes de l'ancienne Égypte (Amsterdam: 1732), vol. 2, chap. 10, 318, 385-86. 
epigrams headed 'Bruchstücke aus Zoroastens Fragmenten (Scraps from the Fragments of Zoroaster),' written by himself. There is nothing even pseudo-oriental about the content, which is mostly sarcastic comment on contemporary social types and attitudes, though Mozart's father enthusiastically reported to his daughter, 'The riddles are just for amusement, but the "Fragments" are really for the encouragement and improvement of morals, which every rational person must work at his whole life long. ${ }^{7}$

Zoroaster is an ancient enough figure to have been mentioned by Plato, and Plutarch briefly outlines what the Greeks understood of his doctrine. ${ }^{8}$ Tradition from there to the eighteenth century associates him with the Magians or Magi, with the worship of fire as a symbol of the Divine, and with belief in two opposed principles of good and evil, symbolized by light and darkness. If, as I take it, the light-darkness opposition in the opera comes mainly out of familiar Enlightenment imagery, reinforced by the common awareness that the Sun was a prime representative of the divine in many early religions, it seems that Schikaneder was using none of that specific-to-Zoroaster background. Apart from the references to Isis and Osiris and the Egyptian décor, which all come from Sethos, Sarastro is more of an all-purpose sage. We could compare him to the Zoroastro in a work that - regrettably for my purposes - probably neither Schikaneder nor Mozart knew (though both accumulated substantial collections of libretti): Händel's opera Orlando of 1733. Imported into Ariosto's story to replace Astolfo and Saint John, Zoroastro opens the opera with an aria on Orlando's sad case - gives him ample advice and warning — rescues both him and the heroine from physical danger by partly magical means - and eventually cures him of his madness. Besides the hermits of Ariosto and Tasso, Händel's Zoroastro descends from devin figures like D'Urfé's Grand Druid Adamas in his pastoral romance L'Astrée, 1627. As a priestly essence of wise old man, Zoroastro, I find, is closer to Sarastro than a figure sometimes cited, the Zoroastre of Rameau's opera so titled (1756), who does carry a bit of Magian mythology with him. Schikaneder's rather eclectic Sarastro not only brings a Persian name into the priesthood of Isis, but in the last scene introduces hero and heroine into what is evidently a temple of the Sun. Rather than speculate that

7 W. A. Bauer, O. E. Deutsch and J. H. Eibl, eds, Mozart: Briefe und Aufzeichnungen (Letters and Records) (Kassel, 1962-75), 3: 506, 521, 524-5; Otto Erich Deutsch, Mozart, A Documentary Biography, trans. Eric Blom, Peter Branscombe, and Jeremy Noble (London: Simon \& Schuster, 1990 [c1965]), 265.

8 Alcibiades, 122; On Isis and Osiris, 46-47. 
Schikaneder - never a great reader - has either seized on one of Osiris's allegorical identifications or confused Terrasson's brilliantly-illuminated Osirian temple of Memphis with the not-far-distant temple of $\mathrm{Ra}$ at Heliopolis, we can guess that he noted the popularity of sun-temple settings at the time and added one of his own.

\section{Schikaneder; Vulpius; Wieland}

The Magic Flute was first performed on September 30th, 1791, at the Vienna theatre run by Emanuel Schikaneder, who had written the libretto (though probably not alone) and commissioned the music. In January 1794, it was produced at the Weimar theatre, in the third year of Goethe's directorship. Christian August Vulpius, whom Goethe employed there as writer and translator, decided that 'It was absolutely impossible to bring the original version of the Zauberflöte ... here to this stage before our refined audience, ${ }^{\prime 9}$ a not untypical response to the libretto at this period when an increasingly educated public prided itself on 'taste' and its own distance from the traditional popular theatre. ${ }^{10}$ To Schikaneder's indignation Vulpius recast the two acts into three, largely reworked the dialogue, and slightly altered the plot - or, as he said, supplied a plot since the original lacked one. His plot changes are small; the most notable is making Sarastro 'ruler of the Empire of the Sun' and brother and successor to the heroine's father - the heroine, of course, is Pamina, but her father continues nameless. Thus, in the early exposition,

9 'Es war uns schlechterdings unmöglich, die Zauberflöte nach dem Originale . . vor unser delikates Publikum hier auf das Theater zu bringen' (A2). In consequence Goethe, who commenced a sequel, along with Herder, Hegel, and Wieland, who all left sage comments, may well have never read the original.

10 See Branscombe 154, 158-59 for other early responses: 'altogether too wretched' (Musikalisches Wochenblatt, Berlin, an October report published Dec. 1791); 'an incredible farce' (Zinzendorf's diary, Nov. 6, 1791); 'This ridiculous, senseless and stale product ...' (Vertraute Briefe zur Charakteristik von Wien (Confidential Letters Characterizing Vienna) (Görlitz: Hermsdorf und Anton, 1793), 2: 50-53. Dieckmann (173) quotes Hegel, who opens a defence of the text, 'How often do we not hear... that the text ... is simply too miserable ...' (Vorlesungen über die Ästhetik [Lectures on Aesthetics] 3 in Werke [Frankfurt am Main: Suhrkamp, 1990], vol. 15, 206). The first known rewriting - Passau, 1793, unsigned - eliminated the Egyptian references, making Sarastro an unspecific 'Mystagog'; it reduced the part of the Queen of the Night (now 'Karmela, eine Zauberinn durch Musik [an enchantress with musical powers]') to a single line, and turned the trials theme into simply a test of love (Die Zauberflöte: Eine grosse Oper in zwey Aufzügen [two acts], ed. Richard Pils [Linz: Verlag für Literatur, Kunst und Musikalien, 1991] — facsimile ed.) 
one of the Queen's three Ladies tells Tamino, 'The gloomy, envious Sarastro, the brother of her ... husband, snatched from the Queen of the Night her husband's crown, and stole from her ... her beloved daughter. ${ }^{11}$ Sarastro's plan is that Pamina shall bestow the crown on Tamino, his own choice for her husband; then, like Sethos before him, he will retire to a life of study and contemplation. ${ }^{12}$

This need to get relationships pinned down is typical of Vulpius, but not of Schikaneder, who is happy to leave things rather loose and associative. Parentage is certainly vague in Schikaneder's Flute. Tamino has a royal father - who indeed has often mentioned the Queen of the Night to him - but we do not learn in what realm, unless we are to draw conclusions from his Japanese hunting-jacket. ${ }^{13}$ Papageno never knew his mother, though he has heard that she once worked for the Queen in her palace; he cannot tell whether the merry old man who raised him was his father. Some of these pieces of information come from Schikaneder's first-act source 'Lulu, oder Die Zauberflöte, ${ }^{14}$ but have been fragmented and recombined. In 2.8 we learn from the dialogue between Pamina and her mother that her father loved and revered the initiates and left his powerful talisman to their leader Sarastro rather than to his widow, who hopes to use Pamina to get it back; that is almost all we hear about Pamina's father, and all we are given about what connects the two men.

However, while Schikaneder drew the opening of his story from the Kunstmärchen 'Lulu,' he made use of other material in the 'oriental' fairy-tale collection from which 'Lulu' comes, Christoph Martin Wieland's Dschinnistan (Genie-Land), 1786-1789. Poet, essayist, dramatist, novelist, review editor, and translator of twenty-two of Shake-

$111.6,20$.

12 2.1, 47-48.

13 On Tamino's 'javonisches/ japonisches Jagdkleid' [Javanese/ Japanese hunting costume] H.-J. Irmen in Mozart's Masonry and The Magic Flute (Zülpich: Prisca, 1996), 223 is certainly right: the letter is a broken 'p,' not 'v.' This exotic garment was perhaps suggested by the 'japonischer Rock' of Prince Balacin, the hero of H. A. von Ziegler's very durable novel about a captive princess, Die asiatische Banise, 1688 (ed. W. Pfeiffer-Belli [Munich: Winkler, 1965]), 18 and passim. Günter Meinhold (see n. 5 above) shares this opinion (75).

14 Christoph Martin Wieland, Dschinnistan, oder auserlesene Feen- und Geister-Mährchen, theils neu übersetzt und umgearbeitet (Genie-Land, or Selected Tales of Fairies and Spirits, in part newly translated and reworked) (Winterthur: Steiner, 1786-1789), vol. 3, 292-351. 'Lulu' is seldom reprinted: see English summary by Peter Branscombe, W. A Mozart, Die Zauberflöte (Cambridge: Cambridge University Press, 1991 - Cambridge Opera Handbooks), 30-31. 
speare's plays (into prose), Wieland was at the time one of Germany's most admired writers. While Dschinnistan has minor contributors, notably A.J. Liebeskind who wrote 'Lulu,' Wieland himself supplied twothirds of it: largely by translations and adaptations from the French, but also two stories he claimed as entirely his own - 'Der Stein der Weisen (The Philosophers' Stone), ${ }^{15}$ and 'Die Salamandrin und die Bildsäule (The Salamandress and the Statue),' which latter provided Schikaneder with those two older-generation figures, Sarastro and his friend.

There is no equivalent to Sarastro in either of the libretto's two major sources. In 'Lulu,' the 'radiant fairy' Perifirime who charges Prince Lulu with recapturing her magic talisman, a gilded tinderbox, from an evil (but unimpressive - mainly comic) magician and gives him the magic flute remains a powerful benevolent figure throughout - characterized, in contrast to the Queen of the Night whose opening function corresponds to hers, by her association with light. However, she does not carry anything like Sarastro's substance, social function, or moral weight. In Terrasson's Sethos, the novel that supplies the Flute's Egyptian and initiatic material, while various unindividualized priests offer instruction, the only figure much resembling a sage is the young prince's wise tutor, who has no equivalent in The Magic Flute. One might guess that Schikaneder called up Sarastro to serve the needs of his story - specifically, to provide an opposing focal figure to the Queen of the Night as the story shifts from fairy-tale to a more impressive kind of ethical fable.

Wieland's 'The Statue and the Salamandress' describes the meeting, in a half-ruined castle in the forests of Brittany, of two young men who confess that they love respectively a statue and a salamandress or female fire-spirit. It is a typical Wieland narrative about youth learning to prefer reality to fantasy. The young men's educational process has been invisibly stage-managed, by means of various prearranged episodes, by their two fathers, who happen to have been friends since long before the birth of their respective sons and, you might guess, also happen to have daughters, both quite human; their sons' encounter in the tower brings on the denouement, which very shortly draws

15 Schikaneder's first 'magic opera' Der Stein der Weisen (1790) derives from the first story in Dschinnistan, 'Nadir und Nadine'; here, promoting the story's rival-magician brothers to divinities linked respectively with sky and underworld, he lets Nadir and us at first darkly suspect the good one, who has snatched Nadine. See Schikaneders heroisch-komische Oper 'Der Stein der Weisen,' ed. David J. Buch and Manuela Jahrmärker (Göttingen: Hainholz, 2002). 
everyone together for the happy ending. These two genuinely wise old men are respectively Kalasiris the high priest of Memphis and also deputy of the Egyptian monarch, and Taranes the High Druid of Brittany, or perhaps - it is not specified - of all of Gaul.

Both these characters have specific literary backgrounds. Lucan mentions in Book 1 of his Pharsalia, enumerating the many tribes that rejoiced when Caesar withdrew his legions from Gaul in order to march on Rome, 'those Gauls who propitiate with human sacrifices the merciless gods Teutas, Esus and Taranis,' and goes on immediately to several lines on the Druids. This is the only reference to Taranis in Classical literature, but the name is known in several forms from some eighty inscriptions, some of them accompanied with sculptures: Taranis was evidently a storm- and thunder-god, a Gaulish Jupiter. ${ }^{16}$ Wieland, usually a well-informed Classical reader, probably had forgotten the bloody associations, but insofar as Taranis is a Gaulish name from a religious context, it is appropriate.

Kalasiris, priest of Isis at Memphis, plays an important part in probably the best-known of the Greek romances after Daphnis and Chloe, the Ethiopica, or Theagenes and Chariclea, by Heliodorus; that Kalasiris even contracts a cross-cultural friendship with a priest of Apollo at Delphi. The romance was translated into most European languages during the sixteenth century; it was much imitated and much borrowed from, by among others Tasso, Cervantes, Racine - and there is a reference in Shakespeare. ${ }^{17}$ Wieland knew the Ethiopica well; he used its plot when shaping the later part of his verse romance Oberon, 1780; Oberon, incidentally, is one of the remoter sources of the Flute, and not exclusively via the version of it that Schikaneder staged in late 1789.

Wieland was much drawn to the late-Classical period that Heliodorus's romance represents, seeing it as an age of emancipation from blind faith and ritual and of free philosophical enquiry. He shared the common assumption of his age, combated but by no means finally demolished by Hume and others, that the religions of the ancient civilizations reflected the pure primal religion; thus they were monotheistic, ethically lofty, and compatible in their essentials with one another - at least as understood by their priests and other initiates, though the popu-

16 Paulys Realencyclopädie der classischen Altertumswissenschaft, ed. Georg Wissowa (Stuttgart: A. Drückenmüller, 1893-1972 - 34 vols. in 68), art. 'Taranis' in Series 2, half-vol. 8, col. 2274-84.

17 Twelfth Night, 5.1.121-3. 
lace might well believe scandalous tales of 'the gods' and worship them in grotesque forms. In 'The Salamandress,' Osmandyas, the son of Kalasiris so to speak on his grand tour, completes his education in the secrets of the primal world, gained at Memphis and Saiis, with a period in Greece being initiated into the Cabirian, Orphic, and Eleusinian mysteries, and two years of visits to assorted cult centres. This highly syncretistic attitude to late-Classical religions helps explain how in the Flute a figure named after Zoroaster turns up officiating in an Egyptian temple; and Wieland's Druid leaves his mark in the later scene (2.28) where Pamina describes how her father at a magic hour in a howling storm carved the magic flute out of the heart of a millennial oak - even though when the Queen's ladies handed the flute in act 1 to Tamino, it was described as 'golden.'

\section{Sun-symbols and sun-temples}

Another powerful talisman in the drama is the 'sevenfold sun-circle' that Sarastro wears on his bosom, inherited from Pamina's father though much desired by his widow. Its invention was evidently prompted by Lulu's being sent on his quest first of all to regain Perifirime's stolen 'jewel,' her gilded tinderbox 'which the spirits of all the elements and all the regions of the earth obey,' and which she received from Lulu's ancestor the wise King Jamshid; only later does she mention the captive Sidi, and with no reference to her being her daughter. While the Queen of the Night, that destructive figure, calls the sun-circle 'all-consuming,' its former owner spoke of Sarastro as one who would rightly wield its powers. If he does so in the opera, it is in the form less of magic, the realm of Perifirime's tinderbox ${ }_{1}^{18}$ than of moral force - its role is to symbolize his wisdom-based authority.

The symbol itself is not easy to explain. Once past the youthful Louis XIV dancing with an embroidered sun spread over his abdomen, ${ }^{19}$ illustrations of the period do not show priestly or kingly figures wearing

18 The magic tinderbox as folktale motif, most familiar in, but considerably older than, Hans Andersen's 1836 'The Tinderbox,' is briefly discussed in Stith Thompson, The Folktale (New York: Dryden, 1946), 71-72.

19 Reproduced, for example, in Claude Dulong, Le mariage du Roi-Soleil (Paris: Albin Michel, 1986), pl. 16. 
suns (except for Confucius in Hogarth's 'Gormogons' print) ${ }^{20}$; and rays surrounding a sun are usually some multiple of four. Perhaps we should envisage seven concentric circles representing the traditional seven planets. ${ }^{21}$ However, an ancient artifact may have prompted Schikaneder to the invention of this symbol. The Abbé Terrasson drew most of his Sethos portrayal of ancient Egypt from Diodorus of Sicily, who describes the tomb of Ozymandias, known to us as Rameses II, as crowned with a massive circle of gold, one cubit thick and 365 cubits around, on which are inscribed the days of the year with their astronomical and astrological indications: it was later looted by the Persians. ${ }^{22}$ Terrasson describes this hefty calendar in Sethos, in a brief catalogue of the treasures of Egypt, as an 'astronomic circle in massive gold' - he reports also the measurements. ${ }^{23}$ While this was hardly an object to be worn as a pendant, a fertile mind like Schikaneder's, glancing through the text for useful hints, could perhaps have transformed it into a small-sized vehicle of authority and power.

The original Magic Flute libretto was, unusually, provided with two engravings (by Ignaz Alberti); these show the temple forecourt described at the end of 2.1 and Papageno with his birdcage. It is in the prints put out by local engravers to take advantage of the interest created by local productions that we must look for images of Sarastro; several of these show him wearing a sun on his breast. No. 3 in the series that is probably the earliest, six engravings by Joseph and Peter Schaffer published in a Brünn journal of 1795 but believed to represent the Brünn production of 1793 , or perhaps even the original Vienna production, show him entering in his lion-drawn 'triumphal chariot,' the sun-emblem visible under his cloak. ${ }^{24}$ Its form is that of a sun-face surrounded with numerous

20 Figure 2. 'The Mystery of Masonry brought to light by ye Gormagons,' the 1724 print by Hogarth in which this figure appears, parodies the processions of the Freemasons, whose Grand Lodge was founded in London in 1717. Confucius with sun-emblem on his breast, a Chinese emperor, and two sages head the procession. While some other figures in the engraving are derived from two or more Don Quixote illustrations by C. A. Coypel (1694-1752), it seems no source is known for this one. See Ronald Paulson, Hogarth's Graphic Works (New Haven: Yale University Press, 1970-1972), vol. 1, 107-08 and vol. 2, pl. 46; see 'Antimasonry: Gormogons' on the useful website run by the Grand Lodge of BC and Yukon: freemasonry.bcy.ca.

21 As known up to 1781, when Herschel discovered Uranus.

22 1.49.5.

23 2: 57.

24 Dieckmann, 184. 
one-line rays. In the series of seven engravings produced in 1794 in Hamburg following Schröder's production of late $1793,{ }^{25}$ one shows Sarastro's triumphal entrance, drawn in apparently by his attendants: he and his fellow-priests wear horn-like mitres, and on his bosom he wears a sun of some thirteen rays. ${ }^{26}$ The Sarastro of the Nuremberg artist Abraham Wolfgang Küffner, in one of eight more sophisticated engravings published in 1797 (though designed in 1795), also wears a sun, attached to bands that cross his chest. ${ }^{27}$

Sun-temples have featured in European drama at least since Dryden's Indian Queen of 1663, set in Peru; usually, as there, they serve as setting for a climactic last act or scene. Illustrations of sun-temple stage sets or costumed sun-priests are rare. However, Schikaneder's direction introducing the Flute's final tableau, 'Sogleich verwandelt sich das ganze Theater in eine Sonne (The whole scene immediately changes to a sun),' doubtless rests on past models reaching back into the Baroque. A theatre print of 1791, the same year as the Flute, shows a sun-temple adorned with colossal statues of priests and priestesses wearing sun-emblems, while a sun fills the centre back. ${ }^{28}$ This represents a production in Olmütz, then in Austria (now Olomouc, Moravia), of the four-act ballet Cora and Alonzo (June 20, three months and ten days before the Flute opened in Vienna). It was one of the several dramas descended from the Peruvian episode in Rameau's Les Indes galantes, 1735 (text by Louis Fuzelier), as reshaped into a brief subplot in Marmontel's Les Incas, 1778: in both a maiden is caught between love and the cult of the divine Sun. Marmontel dedicated his novel to Gustav III of Sweden, who charged his secretary G. G. Adlerbeth and the Saxon composer J. G. Naumann with a dramatization, to be performed 1782 at the inauguration of the Royal Opera in Stockholm. Many translations, adaptations, and reworkings of this 'heroic opera,' Cora och Alonzo, were to follow. Its translation by the Olmütz ballet-master August Huber as Cora und Alonzo, oder Das grosse Sonnenfest in Quito was the third known musical version of the story; the first, Cora, was offered to Mozart by its author, von Dalberg,

25 See $n$. 5 above.

26 Figure 1.

27 Reproduced Dieckmann 199; see 193-201. Rather than reflecting a particular production, these dramatically-focussed designs appear simply to follow the libretto (and Alberti's accompanying 'Papageno' engraving).

28 Figure 3. Gustav Gugitz and Emil Karl Blümml, Die Alt-Wiener Thespiskarren (Old Viennese Travelling Companies) (Vienna: Schroll, 1925), 209. 
at Mannheim in 1778, but never found a composer. Most widely known and translated of this Rameau-Marmontel group was the third play, Kotzebue's Die Sonnenjungfrau (The Sun-Maiden), produced 1789 in Reval (in Estonia, then a Russian province); by 1800 it had, for example, English editions in Edinburgh, Dublin, London (two), and New York. ${ }^{29}$ A short-lived Mannheim periodical, Die rheinische Musen: Zeitung für Theater und andere schöne Künste, 1794-1797, has drawings of characters from The Sun-Maiden, its sequel The Spaniards in Peru, and the Flute: Cora, the Peruvian hero Rolla, and Sarastro all wear similar sun-emblems on their breasts. ${ }^{30}$

In September 1790, just a year before the Flute, the Leopoldstadt Theatre, the main rival of Schikaneder's Theater auf der Wieden, produced Karl Friedrich Hensler and Wenzel Müller's comic opera Das Sonnenfest der Brahminen (The Sun-Festival of the Brahmins), modelled on Kotzebue's play and a considerable success. ${ }^{31}$ Fuzelier's text for Rameau had involved only Peruvian characters; Marmontel's Les Incas brings in the Spaniards, of whom one becomes the lover of Cora. Hensler, while changing the locale to a colourfully-imagined 'Indian isle,' has a young Englishman rescue his English beloved, though a native sunmaiden also plays a part, along with a noble native 'Governor of the Island' who embodies the drama's enlightened moral standards. The Magic Flute narrative has some general resemblances to it, ${ }^{32}$ apart from the concluding sun-temple scene usual in the progeny of Les Incas; at the time when Hensler delivered Mozart's Masonic memorial eulogy (January 1792) and for a further year or so, the two works were seen as somewhat similar and of comparable value. The great Hamburg director F. L. Schröder staged the Flute in November 1793, with five performances in the same month: he remarks, 'And yet only time has given it the

29 See Lawrence Marsden Price, The Vogue of Marmontel on the German Stage (Berkeley: University of California Press, 1944), 87-93; he lists sixteen German versions.

30 Figures 3, 4, 5. 'Cora,' signed Mariane Kirzinger, from vol. 2 no. 1, 1794; 'Sarastro,' signed F[ranz] H. Wolf, from 2.2, 1795; and 'Rolla,' likewise by Wolf, from 3.1, 1795, are reproduced by permission of the Öesterreichische Nationalbibliothek, Vienna.

31 Karl Friedrich Hensler and Wenzel Müller, both very prolific, were respectively house dramatist and music director.

32 See Egon Komorzynski, Emanuel Schikaneder: ein Beitrag zur Geschichte (A Contribution to the History) des deutschen Theaters (Vienna: Doblinger, c1951), 181-84. 
victory over Oberon, and even over The Brahmins' Sun-Festival; both competed successfully with it for at least a year.' ${ }^{33}$

Visiting Frankfurt in April 1791, Schröder saw Kotzebue's SunMaiden, which he himself had staged the year before, and noted the effectiveness of the sun-temple (it appeared again a few days later in Wranitzky's Oberon): '. . . very fine, and put up fast enough. I'm missing a set like that.' In May he reached Vienna in time to see the Sun-Festival's fiftieth performance: clearly works of this kind were much in vogue. ${ }^{34}$ They could all be described loosely as exotic rescue-dramas in which (except for Oberon, which moreover has no sun-theme) the rescue is achieved wholly or in part by conversion of the exotic society to a milder interpretation of the will of its god. Several have grand priest or priestking figures modeled on Marmontel's Ataliba, the royal Inca who comes to be persuaded that the law condemning unfaithful sun-maidens is a human invention, not the will of the divine Sun. While it seems that Schikaneder does have these dramas in mind - Tamino in the Temple of Wisdom fears that Pamina may have been 'sacrificed'35 - resemblances to Sarastro remain quite general.

\section{Conclusion}

Sarastro has two splendid and dignified arias: 'O Isis und Osiris' at the end of 2.1, and 'In diesen heil'gen Hallen / Kennt man die Rache nicht (Within these sacred halls revenge is unknown)' closing 2.12. The first, a prayer to the gods to inspire the young couple with the spirit of wisdom, was evidently suggested by the prayer uttered by the high priest when Sethos, at the end of his ordeals, arrives at sunrise in the temple at Memphis. ${ }^{36}$ The second, in which Sarastro explains that re-

33 Oberon, König der Elfen, a Singspiel based on Wieland's 1780 romantic epic Oberon, was first produced by Schikaneder in 1789 , lightly adapted by K. L. Giesecke from a previous stage adaptation and with music by Paul Wranitzky. The diary entry is from F. L. W. Meyer, Friedrich Ludwig Schröder: Beitrag zur Kunde des Menschen und des Künstlers (A Contribution on the Man and the Artist) (Hamburg, 1819), pt. 2, sect. 2, 115.

34 Meyer, 59, 65, 83.

351.15 .

36 Sethos (bk. 3, 133): 'Isis, ô grande Déesse des Egyptiens, donnez votre esprit au nouveau serviteur qui a surmonté tant de périls \& de travaux pour se presenter à vous. Rendez-le victorieux de même dans les épreuves de son ame en le rendant docile à vos loix; afin qu'il mérite d'être admis à vos mysteres.' 
venge has no place in the life of the wise, very probably developed from the subtitle of an operetta performed in Vienna (presumably at the Leopoldstadt Theatre) in 1790, Leopold Huber's Der unschuldige Betrug, oder Auf dem Lande kennt man die Rache nicht (The Innocent Deception, or In the Country Revenge is Unknown. $)^{37}$ The disparity in period and stature between the two sources once more illustrates Schikaneder's resourcefulness and pragmatism. As he said in two prefaces, he wrote not with an eye to literary values but for immediate stage effect. ${ }^{38}$

This attitude explains many apparent anomalies in the text. If we along with Tamino are to recognize Sarastro as embodying wisdom generally and in particular the just ruler, why does he keep slaves employ the very unsuitable Monostatos to watch over Pamina - and treat his servant to crude irony and a racial slur while promising a particularly cruel punishment? Because Schikaneder is filling in his very vague sense of 'Egypt' from the familiar harem-rescue plays like Mozart's Abduction from the Seraglio whose pashas keep slaves and comically-frustrated harem-watchers, and because this kind of savage joking belongs to the Viennese folk-comedy that is another strain in the work: effect, not consistency, is the driving force. And effects are carefully controlled: just as Monostatos is not actually punished (in 2.7. he says he owes his whole skin to 'this day' - festal because of Tamino's arrival?), there is no hint in Sarastro's arrival of weapons or animal carcasses - the 'hunting' suggestion is confined to its first mention (1.14.)

I suggested that Sarastro was perhaps brought in to balance the Queen of the Night. However, that is working from the traditional assumption that Schikaneder started with the 'Lulu' material - young prince sent on quest by mother of abducted maiden - and then deepened it with the Egyptian-initiatic material from Sethos. My own guess is that the starting-point was rather that friendship in the older generation between

37 O. G. T. Sonneck, Catalogue of Opera Librettos Printed before 1800 (Washington: Government Printing Office, 1914), 2:1293. The composer was Ferdinand Kauer. From 1789 Huber for many years turned out plays and operettas for the Leopoldstadt Theatre.

38 His statements begin '. . . ich schreibe nicht für Leser, ich schreibe für die Bühne ... (I do not write for readers but for the stage)' (preface to Der Grandprofos [The Provost-Marshal], Regensburg, 1787), and 'Ich schreibe fürs Vergnügen des Publikums, gebe mich für keinen Gelehrten aus ... (I write for the enjoyment of the public, I don't profess to be a scholar)' (preface to Der Spiegel von Arkadien [The Mirror of Arcadia], Vienna, 1794). 
high priest and High Druid, and that he deliberately loosened that up by first subtracting two sons and one daughter, leaving Pamina as the one child; and second, replacing Pamina's father in the present with his angry widow - the surviving friend's antagonist. Deliberately, because either the 'Salamandress's' two pairs of lovers or the two smirking fathers at the end of both that story and 'Lulu' - where Perifirime assembles both her old lover the king of Kashmir, father of her daughter Sidi, and Lulu's father the king of Khorasan - would make his plot too closed, too lightweight, too old-fashioned. Then for hero and opening situation he draws on 'Lulu,' giving the fairy's role to the Queen of the Night (a name complementary to her rival's Osiris = Sun connection ${ }^{39}$ ), and for the remainder he brings in Sarastro, the surviving friend, and develops around him a loftier tone and initiatic narrative deriving from Sethos.

In this libretto, with all its shortcomings, Schikaneder surpasses his previous successes, aided by experience both long and wide and a fine-tuned theatrical sensibility. He is ambitious: he loves especially the challenge of new, unhackneyed effects; and he knows that his friend Mozart like him is eager and able to wed the comic-romantic with the sublime.

\section{JAY MACPHERSON \\ Victoria College}

39 Diodorus says the early Egyptians called the sun and moon Osiris and Isis (Library of History 1. 11. 1-2); witness Isis' starry robe in Apuleius (Golden Ass 11. 3-4). Thus Isis could show herself as a Queen of the Night; some have found here a spur to ingenuity: cf. Jacques Chailley, 'La Flûte Enchantée,' opéra maçonnique: essai d'explication du livret et de la musique (Paris: Robert Laffont, c1968), esp. 105-09; Wolfgang Schmidbauer, Das Geheimnis der Zauberflöte: Symbole der Reifung - Wege zur Integration (Freiburg: Herder, 1995), 21-23, 63-67 (this is a respectable Jungian reading); Michael Besack, Which Craft? W. A. Mozart and 'The Magic Flute' (Oakland, CA: Regent Press, 2001), 214-18. 


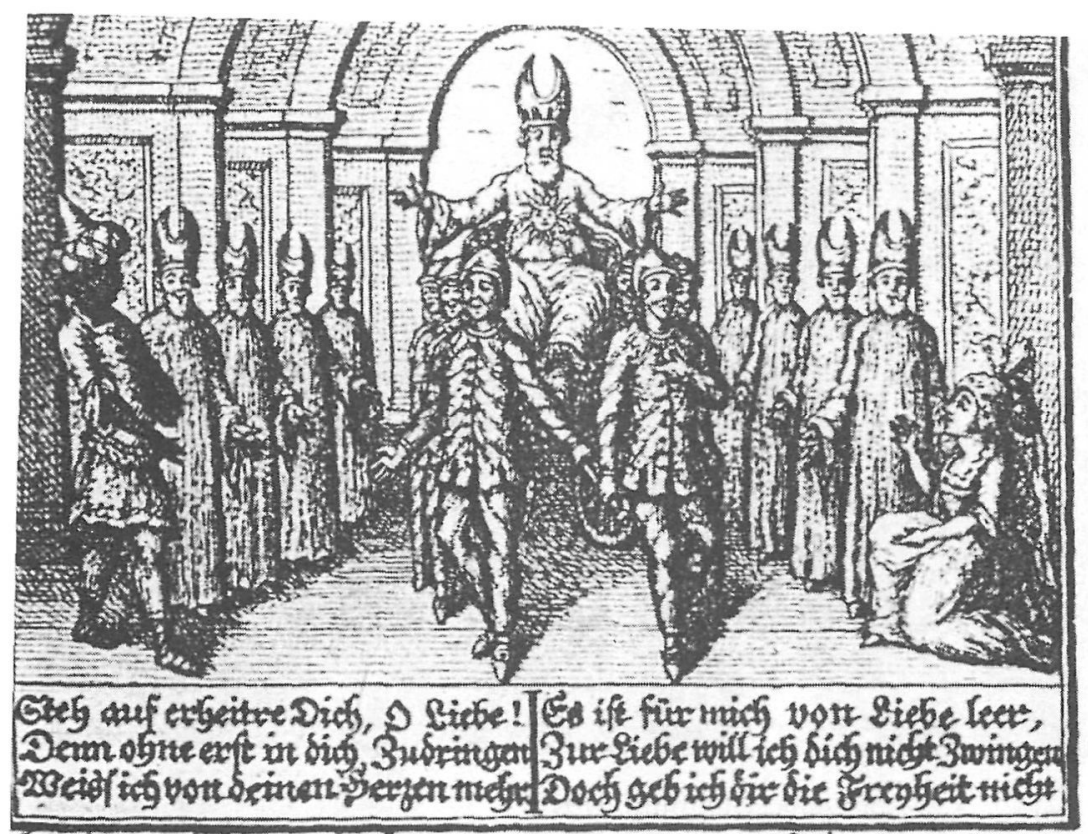

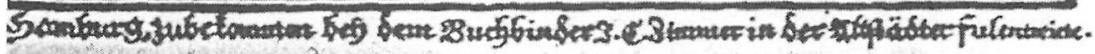

Figure 1. The Magic Flute, Hamburg, 1794 


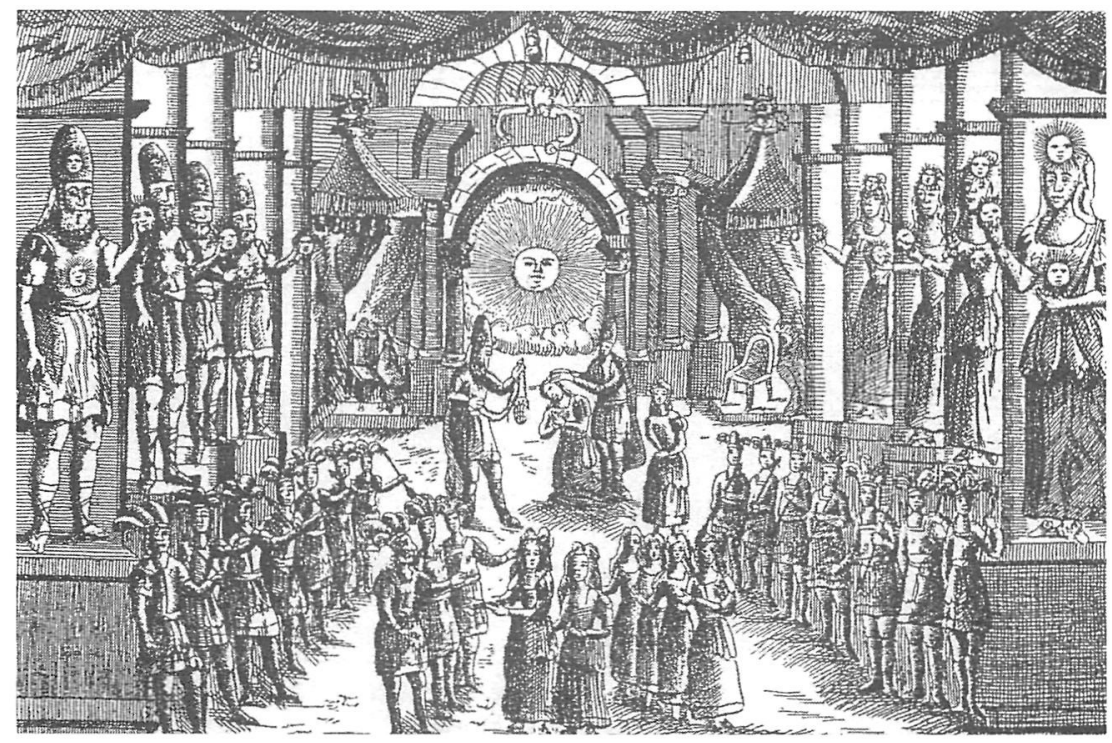

Figure 2. Cora and Alonzo, Olmütz, 1791 


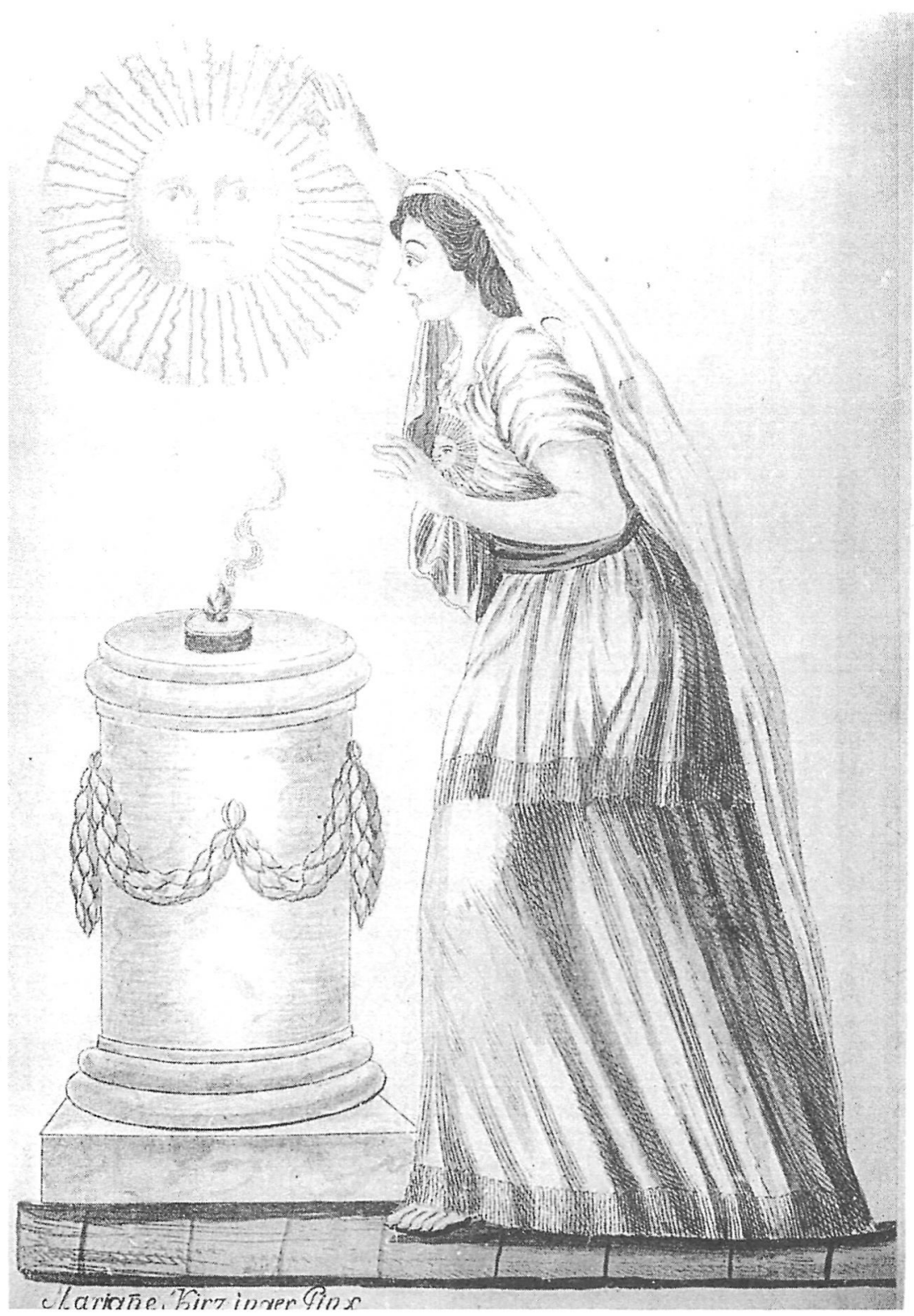

Figure 3. Cora, from The Sun-Virgin, Mannheim, 1794 


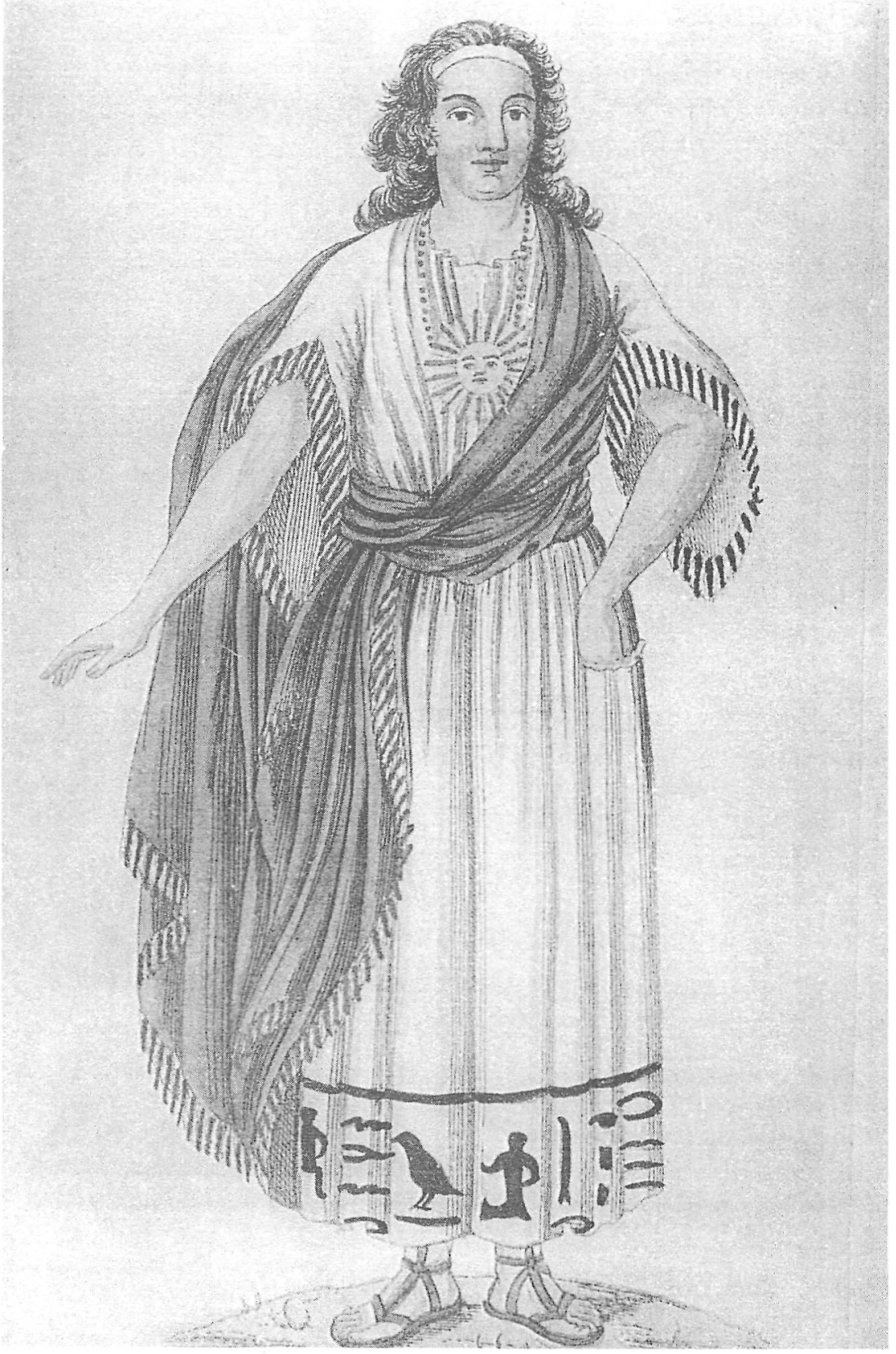

Figure 4. Sarastro, from the Magic Flute, Mannheim 1795 


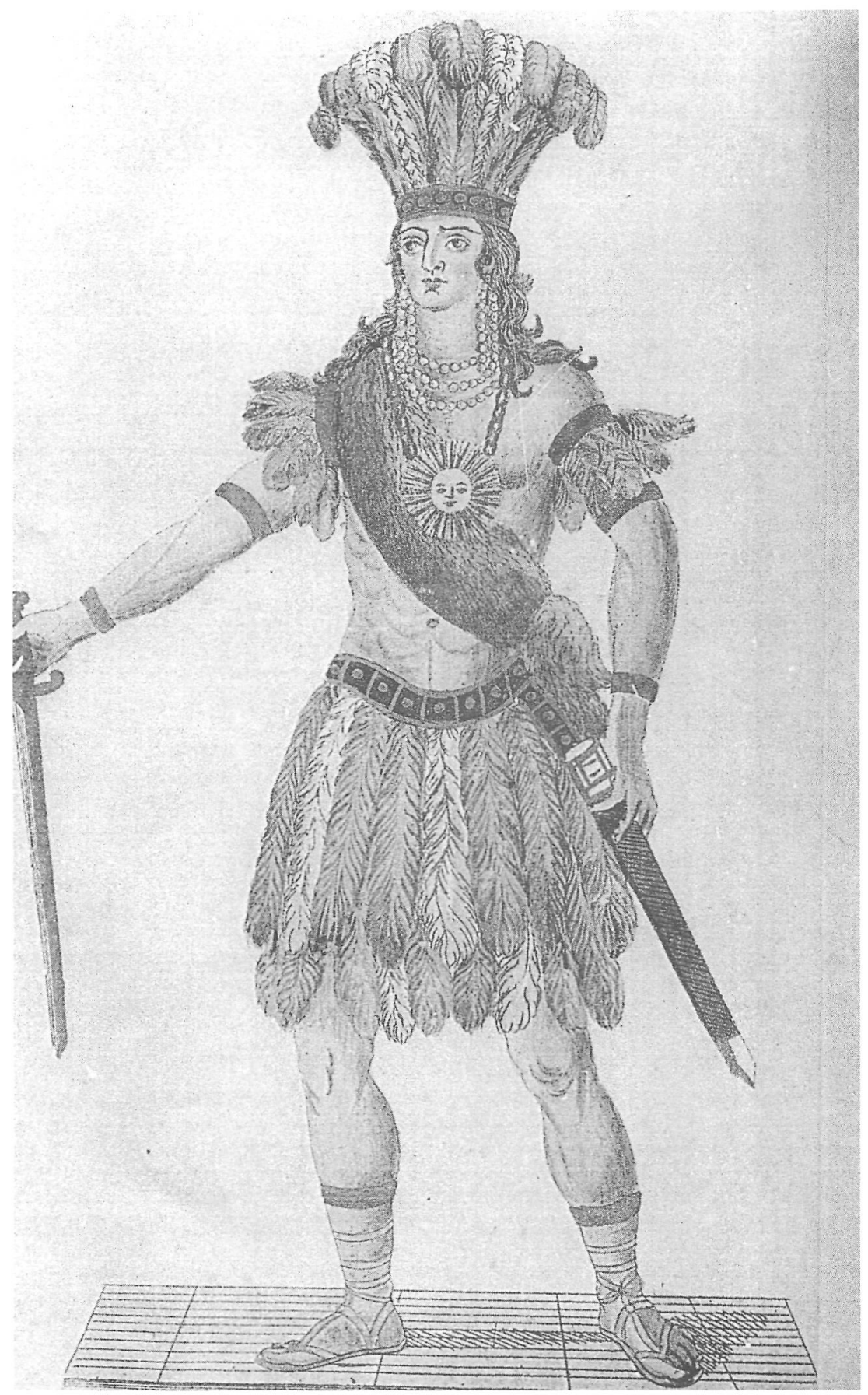

Figure 5. Rolla, from the Spaniards in Peru, Mannheim, 1795 